\title{
SOSIALISASI PEMBUATAN JARINGAN PIPA IRIGASI TETES UNTUK DAERAH IRIGASI LAHAN KERING DI DESA TUMPAK KECAMATAN PUJUT KABUPATEN LOMBOK TENGAH
}

\author{
Sasmito' Suryawan Murtiadi, Anid Supriyadi, Salehuddin, I Wayan Yasa \\ Jurusan Teknik Sipil, FT, Mataram, Indonesia; \\ Alamat korespondensi : sasmitosoekarno@unram.ac.id
}

\begin{abstract}
ABSTRAK
Desa Tumpak terletak di Kecamatan Pujut, Kabupaten Lombok Tengah. Luas Desa Tumpak 3454 Ha dengan $80 \%$ berupa lahan kering. Dengan kondisi wilayah tersebut, maka masalah utama Desa Tumpak adalah terbatasnya sumber daya air. Produksi pertanian hanya pada musim penghujan, selebihnya lahan dibiarkan menganggur karena tidak tersedia air irigasi. Lokasi Desa Tumpak berdampingan dengan Kawasan Ekonomi Khusus (KEK) Mandalika, sehingga Desa Tumpak berpotensi untuk menjadi kawasan penyangga KEK Mandalika terutama untuk mensuplai kebutuhan bahan makanan berupa sayur mayur yang diperlukan oleh hotel dan restauran. Oleh karena itu digagas untuk meningatkan produksi pertanian yang berkesinambungan yang setiap saat lahan bisa ditanami dengan cara menyediakan air irigasi dengan membangun sistem irigasi tetes. Prinsip sistem irigasi tetes adalah menyalurkan air langsung ke zona perakaran tanaman melalui jaringan pipa distribusi, dengan demikian dapat menghemat air karena dicegah kehilangan air yang berlebihan. Air dialirkan dari sumber air ke resevoir yang elevesainya lebih tinggi dari lahan pertanian. Air distribusikan secara gravitasi ke lahan melalui pipa utama dan pipa pembagi ke lahan. Pipa pembagi diberi lubang-lubang kecil untuk meneteskan air di lokasi tanaman. Jarak tiap lobang sesuai dengan jarak tanaman yang diairi. Sosialisai irigasi tetes di Desa Tumpak dilaksanakan di Aula Desa Tumpak yang dihadiri oleh 22 peserta yang terdiri atas perwakilan petani dan kepala dusun setempat. Sosialisai meliputi konsep dan cara pembuatan jaringan pipa irigasi tetes, dan dilengkapi dengan peragaan pembuatannya. Peserta sangat senang dan bersemangat untuk membangun jaringan pipa di lahan masing-masing. Peserta minta bimbingan lanjutan yang dipertimbangkan untuk kegiatan pengabdian berikutnya dan untuk kegiatan PKM.
\end{abstract}

Kata Kunci : Lahan- kering, irigasi-tetes, jaringan-pipa

\section{PENDAHULUAN}

Desa Tumpak merupakan salah satu desa yang terletak di Kecamatan Pujut Kabupaten Lombok Tengah. Desa Tumpak mempunyai luas wilayah cukup besar yakni sebesar $3454 \mathrm{Ha}$, dengan $80 \%$ berupa lahan kering. Sebagian besar masyarakat Desa Tumpak adalah buruh tani, peternak, nelayan dan profesi lain. Sebagian besar lahan Desa Tumpak merupakan lahan pertanian irigasi lahan kering, setiap tahunnya meghasilkan hasil pertanian berupa sayursayuran. Desa Tumpak memanfaatkan hasil pertanian sayur mayur, perternakan sapi, dan hasil laut untuk meningkatkan kemajuan ekonomi masyarakat.

Usaha pertanian dan peternakan merupakan modal pokok lapangan pekerjaan bagi masyarakat, baik di lahan pekarangan rumah maupun di lahan perkebunan yang berupa lahan hamparan yang sangat kering. Kendala usaha pertanian pada lahan kering adalah terbatasnya sumber daya air, sehingga produksi pertanian berlangsung hanya pada musim penghujan selebihnya lahan dibiarkan menganggur karena tidak tersedia air irigasi. Lokasi Desa Tumpak berdampingan dengan Kawasan Ekonomi Khusus (KEK) Mandalika, sehingga Desa Tumpak berpotensi untuk menjadi kawasan penyangga KEK Mandalika terutama untuk mensuplai kebutuhan bahan makanan berupa sayur mayur yang diperlukan oleh hotel dan restauran. Oleh karena itu diusahakan untuk meningatkan produksi pertanian yang berkesinambungan yang setiap saat lahan bisa ditanami dengan cara menyediakan air irigasi dengan membangun sistem irigasi tetes. 
Sistem irigasi tetes merupakan sistem irigasi yang sesuai untuk diterapkan pada lahan kering, karena sistem irigasi tetes ini sangat hemat air dengan mencegah kehilangan air sebanyak mungkin. Air dialirkan melalui haringan pipa dan didistribusikan langsung ke zona perakaran sehingga dapat mencegah kehilangan air yang berlebihan seperti penguapan dan perkolasi. Permasalahan di lapangan adalah bahwa mitra (petani) di Desa Tumpak belum paham tentang sistem irigasi ini, sehingga dilaksanakan sosialisasi pembuatan jaringan pipa irigasi tetes. Target sosialisasi adalah agar mitra petani Desa Tumpak paham dan mampu mengembangkan/membuat sistem irigasi tetes secara mandiri.

Desa Tumpak merupakan desa yang cukup besar. Sebagian besar masyarakat Desa Tumpak adalah buruh petani, peternak, nelayan dan lain-lain. Sebagian besar lahan Desa Tumpak merupakan lahan pertanian kering, sehingga produksi pertanian hanya berlangsung saat musim penghujan. Hasil pertanian sebagian besar berupa sayur-sayuran. Desa Tumpak memanfaatkan hasil pertanian seperti sayuran, perternakan, dan hasil laut untuk meningkatkan kemajuan ekonomi masyarakat. Ada beberapa masalah di desa tersebut yakni terbatasanya sumber air, sanitasi lingkungan yang sangat kurang baik, kurangnya bak sampah, dan masih rendahnya tingkat Sumber Daya Manusia nya.

Lahan pertanian dan peternakan merupakan modal pokok lapangan kerja bagi masyarakat, baik lahan pekarangan rumah maupun lahan perkebunan. Semua lahan tersebut berupa lahan hamparan yang sangat kering. Desa Tumpak sebagian besar areal persawahannya beruapa tanah Clay, yang sangat peka dengan kadar air. Oleh karena itu diperlukan infrastruktu untuk menjaga kelengasan tanah agar struktur tanah tidak sering berubah yang mengganggu pertumbuhan tanaman. Infrastruktur yang sesuai adalah sistem irigasi tetes. Sistem ini sangat hemat air karena kehilangan air dapat diminimalisir dengan mengalirkan air langsung ke zona perakaran sehingga evaporasi dan perkolasi dapat dicegah. Selain itu distribusi air menggunakan pipa sehingga kehilangan air akibat resapan dan evaporasi juga dapat diminimalisir.

Mitra petani Desa Tumpak belum terbiasa dengan sistem irigasi tetes ini, oleh karena itu diadakan sosialisasi kepada mitra petani agar mitra petani paham dan mampu membuat jaringan irigasi tetes. Tujuan kegiatan utama program pengabdian ini adalah sosialisasi kepada masyarakat tentang sistem irigasi tetes yang meliputi teori sistem irigasi tetes, dan peragaan pembuatan jaringan pipa irigasi tetes. Kegiatan sosialisasi ditujukan kepada mitra petani sehingga mitra petani paham dan mampu membuat jaringan pipa irigasi tetes.

\section{Pelaksanaan sosialisasi irigasi tetes}

\section{METODE}

Sosialisasi dilaksanakan pada tanggal 17 Nopember 2020. Materi sosialisasi meliputi sosialisasi teori, dan demonstrasi cara pembuatan jaringan pipa irigasi tetes. Acara sosialisasi bertempat di Aula Kantor Desa Tumpak yang dihari oleh peserta yang terdiri atas wakil petani dan wakil kepala dusun setempat. Pelaksanaan sosialisasi dilakukan oleh tim yang terdiri dari 5 orang dosen Jurusan Teknik Sipil Universitas Mataram.

\section{Materi sosialisasi}

Materi sosialisasi berupa teori sistem jaringan pipa yang diperoleh dari Balitbang PUPR (elearning.litbang.pu.go.id, 2020) berupa video konsep jaringan pipa irigasi tetes, dan cara pembuatan jaringan pipa. Skema jaringan pipa sistem irigasi tetes ditunjukkan Gambar 1. Sistem jaringan pipa irigasi tetes 3 komponen utama, yakni: 


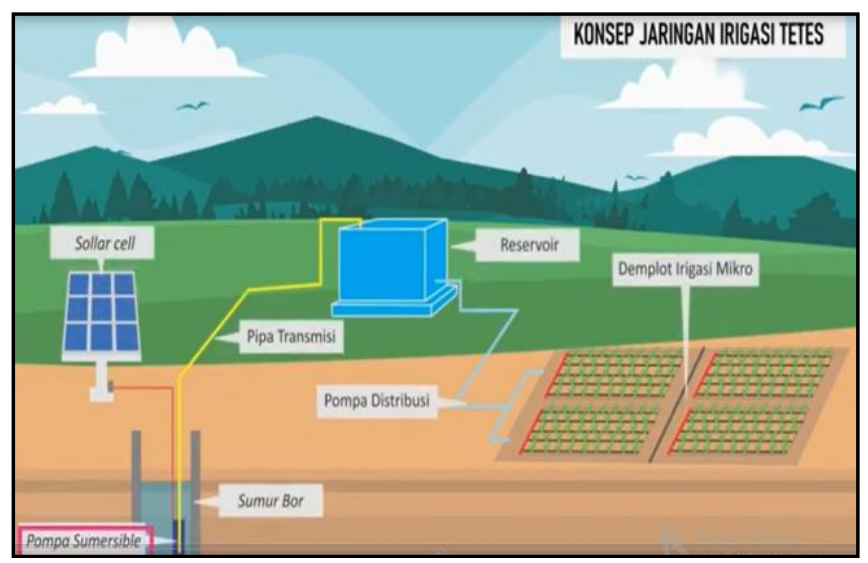

Gambar 1. Skema jaringan pipa sistem irigasi tetes

(Sumber: elearning.litbang.pu.go.id, 2020)

\section{a. Sumber air}

Sumber air di lahan kering bisa berupa: sumur bor, embung, atau sungai. Air dari sumber air dipompa melalui pipa menuju reservoir (bak air) yang mempunyai ketinggian lebih besar dibanding ketinggian permukaan lahan. Sumber energi untuk menggerakkan pompa berupa energi listrik, dapat memakai energi listrik PLN. Jika tidak tersedia dipakai sumber energi listrik yang berasal dari sel surya. Untuk daerah-daerah terpencil pemakaian energi listrik dengan sel surya lebih efektif karena harga peralatan sel surya semakin murah.

a. Reservoir

Air yang berasal dari sumber air dipompa dan dialirkan ke reservoir atau bak penampungan yang dapat berupa tangki air. Elevasi dasar reservoir dibuat lebih tinggi dari lahan minimal $1 \mathrm{~m}$ agar tersedia tinggi tekanan yang cukup untuk mengalirkan air secara gravitasional ke lahan. Selanjutnya air didistribusikan ke lahan pertanian menggunakan pipa distribusi ke blok irigasi mikro tempat tanaman ditanam. Besar bak air disesuaikan dengan luasan blok irigasi yang ada, untuk seluas $100 \mathrm{~m}^{2}$ diperlukan tangki air kapasitas 250 liter $(0,25$ $\left.\mathrm{m}^{3}\right)$.

c. Blok irigasi mikro

Air dari pipa distribusi dialirkan ke lahan blok irigasi mikro melalui pipa pembagi yang diberi lubang kecil untuk meneteskan air ke tanaman. Jarak lubang tetes ini disesuaikan dengan jarak tanaman.

\section{Cara pemberian air}

Pemberian air diatur sesuai dengan kebutuhan tanaman, namun pada dasarnya pemberian air dapat berlangsung terus menerus selama 24 jam. Kapasitas resevoir air yang diperlukan untuk lahan seluas 1 are adalah sebesar 250 liter. Reservoir (tangki air) diisi penuh 2 kali dalam sehari semalam, yakni diwaktu pagi dan sore hari. Besar kecil atau frekuensi tetesan dapat diatur melalui keran pelepas yang terpasang pada ujung hulu pipa pembagi.

\section{Hasil}

\section{HASIL DAN PEMBAHASAN}

\section{a. Peserta sosialisasi}

Kegiatan sosialisasi dilakukan dengan cara tatap muka yang berlangsung di Aula Kantor Desa Tumpak pada tanggal 17 Nopember 2020. Peserta sosialisasi berjumlah 22 orang yang terdiri atas wakil petani dan wakil kepala dusun. Pelaksanaan sosialisasi mengikuti aturan protokol kesehatan yakni memakai masker dan menjaga jarak. Oleh karena itu setiap peserta diberi masker dan tempat duduknya diatur berjarak sesuai protokol kesehatan. Acara dihadiri kepala Desa Tumpak Bpk Rosadi, S.Pd.I dan beberapa staf Desa. 


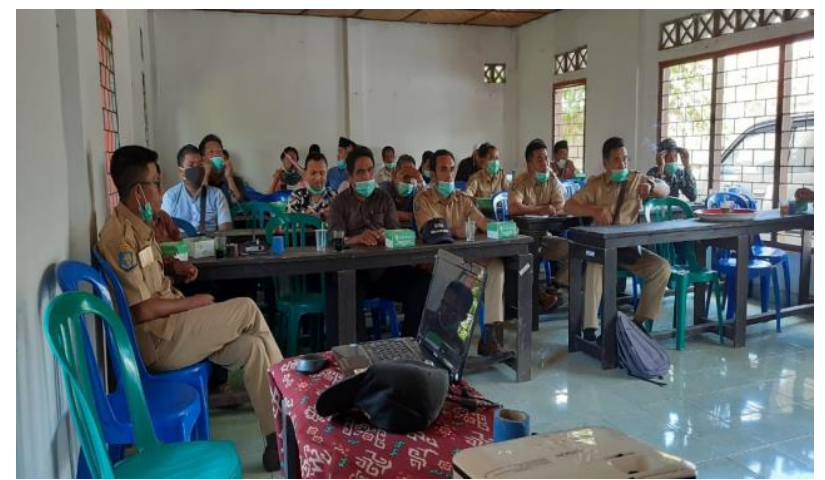

Gambar 2. Acara sosialisasi di Aula Kantor Desa Tumpak

b. Pemaparan materi

Pemaparan materi dibagi 2 sesi, sesi pertama menjelaskan materi sistem irigasi tetes menggunakan media presentasi slide dan pemutaran video irigasi tetes dari Balitbang PU.

Materi yang disampaikan meliputi:

1) Konsep irigasi tetes

2) Struktur jaringan pipa irigasi tetes

3) Sistem pengisian reservoir

c. Peragaan pembuatan jaringan pipa

Peragaan pembuatan jaringan pipa dilaksanakan tetap di dalam Aula Kantor Desa Tumpak, hal ini dilakukan untuk menjaga agar tidak terjadi kerumunan masa. Konsekuensinya tidak diadakan peragaan aliran air karena akan menimbulkan genangan air di lantai aula.

\section{Pembahasan}

a. Materi sosialisasi

Materi yang disampaikan dibuat sederhana agar mudah dipahami peserta. Materi sistem jaringan pipa irigasi tetes dipaparkan secara lengkap mulai dari sumber air hingga ke pipa pembagi ke tanaman. Peserta cukup semangat dengan memberikan pertanyaan tentang teori irisasi tetes, dan cara pembuatan jaringan pipa.

b. Fasilitas penunjang

Sebagian besar wilayah Desa Tumpak telah tersedia jaringan listrik PLN sehingga ketersediaan energi untuk menggerakkan pompa air tidak menjadi masalah. Hal yang menjadi kendala adalah ketersediaan air, sumur bor yang ada terbatas jumlahnya. Oleh karena itu, diusahakan untuk dapat dibangun sumur bor irigasi baru dengan cara mendorong masyarakat untuk mengajukan proposal pengadaan sumur bor ke dinas terkait.

c. Respon peserta

Setelah acara selesai seorang peserta yakni Mahyudin yang mewakili petani dari Dusun Bun Pek menginginkan untuk membuat jaringan irigasi tetes. Keinginan ini diakomodasi dan dijadikan program kegiatan pengabdian masyarakat tahun depan atau untuk dijadikan kegiatan untuk PKM.

\section{KESIMPULAN}

Dari uraian tersebut dapat disimpulkan hasil pengabdian sebagai berikut.

a. Peserta bisa menerima dan memahami konsep sistem irigasi tetes dan cara pembuatannya

b. Sistem irigasi tetes sangat diminati oleh mitra petani di Desa Tumpak. Mereka sangat berminat untuk bisa mewujudkan keinginannya, dan menginginkan bimbingan lebih lanjut. 
c. Program sosialisasi akan dilanjutkan tahun depan untuk membuat percontohan jaringan irigasi tetes di Dusun Bun Pek Desa Tumpak.

\section{UCAPAN TERIMA KASIH}

Penulis menyampaikan terima kasih kepada Universitas Mataram yang telah menyediakan dana untuk menyelesaikan pengabdian ini, serta semua pihak yang telah membantu sehingga kegiatan ini berlangsung lancar.

\section{DAFTAR PUSTAKA}

Linsley, R. Kohler, dan Franzini, J.B., 1991, Hidrologi Untuk Insinyur, Penerbit Erlangga, Jakarta.

Marshall, T.J., Holmes, J.W. dan Rose, C.W. (1996). Soil Physics. Third Eddition. Cambridge University Press.

Sosrodarsono, Suyono., 2006, Hidrologi Untuk Pengairan, Pradnya Paramita, Jakarta

Streeter, V.L, ylie, B.E. dan Prijono A., 1988, Mekanika Fluida Edisi Delapan Jilid 2, Penerbit Erlangga, Jakarta. 